Rodrigo Rodrigues Adão

\title{
Household Income and Strategic Default Decision in the Subprime Crisis
}

Thesis presented to the Postgraduate Program in Economics of the Departamento de Economia, PUC-Rio as partial fulfillment of the requirements for the degree of Mestre em Economia

Advisor: Prof. Walter Novaes 


\section{Household Income and Strategic Default Decision in the Subprime Crisis}

Thesis presented to the Postgraduate Program in Economics of the Departamento de Economia, PUC-Rio as partial fulfillment of the requirements for the degree of Mestre em Economia. Approved by the following commission:

Prof. Walter Novaes

Advisor

Departamento de Economia - PUC-Rio

Prof. Marco Antonio Cesar Bonomo

EPGE

Prof. Vinícius Nascimento Carrasco

PUC-Rio

Prof. Mônica Herz

Coordinator of the Social Science Center - PUC-Rio

Rio de Janeiro - April 11, 2011 
All rights reserved.

\section{Rodrigo Rodrigues Adão}

Rodrigo Adão graduated in Economics from PUC-Rio in 2007.

He then worked as a bond trader for Ciano Investment in 2008.

Bibliographic data

Adão, Rodrigo Rodrigues

Household Income and Strategic Default Decision in the Subprime Crisis / Rodrigo Rodrigues Adão ; advisor: Walter Novaes. - 2011.

$61 \mathrm{f}$ : : il. ; $30 \mathrm{~cm}$

Dissertação (Mestrado em Economia)-Pontifícia Universidade Católica do Rio de Janeiro, Rio de Janeiro, 2011.

Inclui bibliografia

1. Economia - Teses. 2. Hipoteca. 3. Inadimplência. 4. Valor líquido imobiliário negativo. 5. Finanças familiares. I. Novaes, Walter. II. Pontifícia Universidade Católica do Rio de Janeiro. Departamento de Economia. III. Título.

CDD: 510 


\section{Acknowledgments}

Ao meu orientador Professor Walter Novaes pelo estímulo, apoio e parceria.

Aos meus pais Horácio e Ana Cristina, pela educação, apoio e incentivo. Aos meus irmãos Camila e Filipe pelo apoio e incentivo.

Aos meus amigos Breno, André e Pablo pelas discussões e sugestões que contribuiram para a elaboração deste trabalho.

Aos meus colegas e amigos da PUC-Rio.

Aos professores que participaram da banca examinadora.

A todos os professores e funcionários do Departamento pelos ensinamentos e pela ajuda.

A todos os amigos e familiares que de uma forma ou de outra me estimularam ou me ajudaram.

Ao $\mathrm{CNPq}$, ao Departamento de Economia da PUC-Rio, à FAPERJ, à Vinci e à PUC-Rio, pelos auxílios concedidos, sem os quais este trabalho não poderia ter sido realizado. 


\section{Abstract}

Adão, Rodrigo Rodrigues; Novaes, Walter (Advisor). Household Income and Strategic Default Decision in the Subprime Crisis. Rio de Janeiro, 2011. 61p. Dissertação de Mestrado - Departamento de Economia, Pontifícia Universidade Católica do Rio de Janeiro.

Between 2006 and 2010, the price of houses in the United States fell by $30 \%$, implying that a large number of mortgage contracts had negative equity value, that is, a debt outstanding higher than the house value. In these mortgage contracts, it pays for the borrowers to exchange their homes for the write-off of the debt. And yet, the delinquency rate among negative equity mortgages is surprisingly low.

This paper argues that the fear of losing access to the credit markets explains why the delinquency rate remained relatively low in the U.S. after the Subprime crises. Our model shows that, with the end of the bubble in the housing market, low-income families are unlikely to qualify for the mortgage contracts they hold. Hence, fear of losing access to credit market lowers their incentive to walk away from their current mortgage contracts, even if they have negative equity value. Using a panel of US states to test the existence of this effect, we show that delinquency is more sensible to a decrease of house prices in areas with higher per capita income.

\section{Keywords}

Mortgage. Mortgage Default. Negative Equity. Household Finance. 


\section{Resumo}

Adão, Rodrigo Rodrigues; Novaes, Walter (Orientador). Renda Familiar e Decisão de Default Estratégico na Crise do Mercado Imobiliário. Rio de Janeiro, 2011. 61p. Dissertação de Mestrado — Departamento de Economia, Pontifícia Universidade Católica do Rio de Janeiro.

Entre 2006 e 2010, os preços de imóveis nos EUA caíram cerca de 30\%, fazendo com que o principal de um grande número de contratos de hipoteca ficasse abaixo do valor do imóvel. A teoria de default estratégico prediz que devedores nessa situação - chamada de "negative equity value" - deveriam entregar o imóvel e abandonar o contrato. Entretanto, a taxa de default em hipotecas com "negative equity value", além de ser surpreendentemente baixa.

Esta dissertação explica a baixa taxa de default no mercado americano de hipotecas a partir de preocupações dos credores em conseguir crédito imobiliário no futuro. O modelo mostra que tal preocupação é mais grave para devedores de baixa renda que se beneficiaram do crédito facilitado advindo da explosão de preços dos imóveis, mas que estão cientes de que tais facilidades provavelmente não estarão presentes no futuro. Os credores de baixa renda, portanto, têm mais incentivos a evitar default em hipotecas de "negative equity value" do que credores de mais alta renda, que antecipam facilidades em obter novo crédito imobiliário. Utilizando um painel de estados dos EUA para testar a existência deste efeito, mostramos que a inadimplência é mais sensível à queda no preço dos imóveis em áreas com maior renda per capita.

\section{Palavras-chave}

Hipoteca. Inadimplência. Valor líquido imobiliário negativo. Finanças familiares. 


\section{Contents}

1 Introduction $\quad 10$

2 A Simple Model $\quad 14$

2.1 The model 14

\begin{tabular}{ll}
2.2 & Strategic default decision \\
\hline
\end{tabular}

2.3 Who gets access to the credit market? 19

2.4 Economy's Mortgage Delinquency 21

3 The General Model $\quad 23$

3.1 Agents and Time Horizon 23

$\begin{array}{ll}3.2 \text { Housing Supply } & 24\end{array}$

3.3 Mortgage Contract 24

3.4 Returning to the mortgage market 25

$\begin{array}{ll}3.5 & \text { The borrower's problem } \\ \end{array}$

$4 \quad$ Solving The Model $\quad 27$

4.1 The Gain from Walking Away 27

4.2 Gain from Paying the Mortgage $\quad 29$

5 Simulations 33

5.1 Who has access to the mortgage market? 34

6 Testing the wealth effect on strategic default 36

$\begin{array}{lll}6.1 & \text { Data } & 37\end{array}$

6.2 Results 38

6.3 Robustness Checks and Endogenicity Problems 39

7 Conclusion 42

8 References $\quad 43$

$\begin{array}{lll}\text { A Proofs } & 44\end{array}$

$\begin{array}{ll}\text { B Tables and Figures } & 57\end{array}$ 


\section{List of Figures}

B.1 Timing of events 57

B.2 Mortgage characteristics on 220 thousand of dollars house for several bubble burst probabilities and initial wealth values. 


\section{List of Tables}

B.1 Model Simulation - Mortgage on 220 thousand of dollars house 58

B.2 Summary Statistics: Variables Means per Year. 60

B.3 Testing the wealth effect on strategic default 61 